\title{
ON THE VALUE OF THE NITROGEN FACTOR IN THE ANALYSIS OF DECOMPOSED MILK.
}

By Alfred Smetham, F.I.C., F.C.S., and J. B. Ashworth, F.C.S.

(Read at the Meeting, May 5, 1897.)

HAviNG in the latter part of last year under examination a sample of milk which had undergone decomposition, it occurred to one of us that a more reliable opinion of the original composition could be obtained by estimating the nitrogen and ash, and thus calculating the original percentage of casein and albumen and ash present in the sample, than by attempting to estimate the total solids-not-fat, and calculating by any system of correction back to the fresh condition of the milk. In investigations which we had conducted upon the cheese-making industry of Cheshire on behalf of the Board of Agriculture, we had been struck by the comparatively constant contents of casein and albumen in the mixed milk of herds from various sources and at different 
times; and as our experiments had further shown that the production of lactic acid commences at a very early stage of decomposition, it seemed pretty clear that any ammonia formed by fermentation of the nitrogen compounds would be fixed, and as long as the milk remained acid an estimation of nitrogen (unless free nitrogen were evolved) would yield results identical-exeept so far as there was loss of weight of the sample-with those obtained in the analysis of the fresh milk.

In this connection the following figures, obtained by titrating milk with KHO, using phenolphthalein as indicator, may prove interesting:

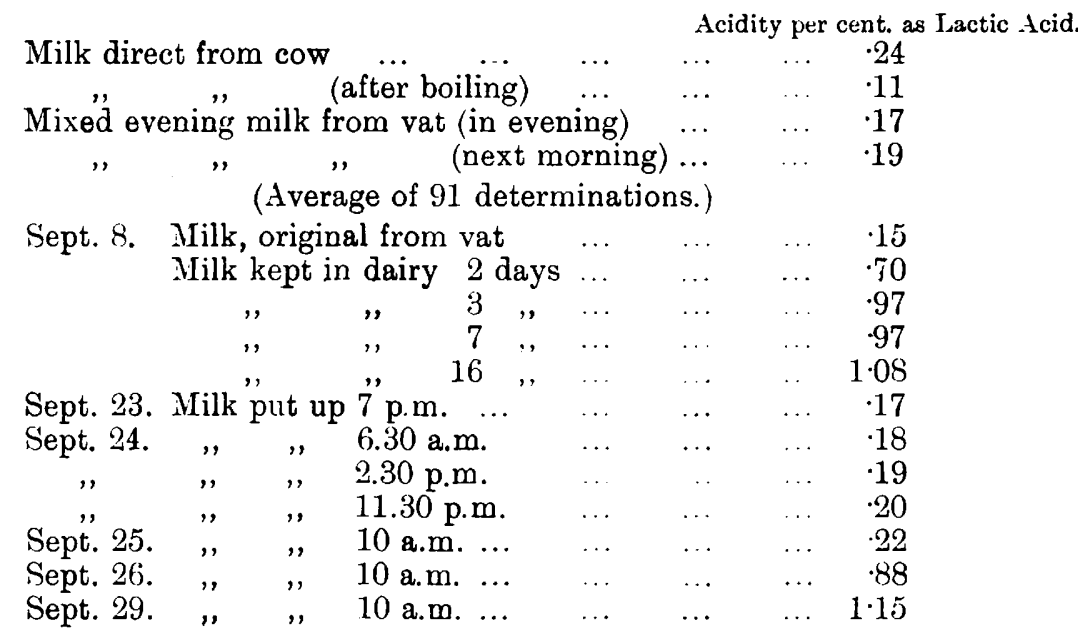

The sample of milk marked No. 8 in the tables, after being kept for thirteen weeks gave, on distillation with magnesia, ammonia $=055$ per cent., and it will be seen that up to that time the lactic acid is much in excess of the ammonia produced.

To ascertain to what extent changes in the nitrogen contents of milk took place during keeping, we started a series of experiments, the results of which we have now the honour to present to you.

The method adopted was as follows: Nine milks from various sources, of the purity of which there was no doubt, were obtained and analysed, the total solids dried to constancy at $100^{\circ} \mathrm{C}$, the fat estimated by Adams' process, using Schleicher and Schïll's fat-free paper (which gave only 0.0005 gramme of residue on extraction with ether), the nitrogen estimated in duplicate by the Kjeldahl-Gunning-Arnold process, in exactly the manner described by our President (Journal, Chemical Society, lxvii., 811), the water of the milk being evaporated over a low flame after the addition of the sulphuric acid, the nitrogen $\times 6.33$ stated as casein and albumin. The milksugar, etc., was obtained by difference.

At the same time that the quantities for the analyses were weighed out, six portions of about 10 grammes were accurately weighed in sterilized glass bottles of about 15 c.c. capacity, and these were corked, kept at the ordinary temperature of the laboratory, and the nitrogen estimated at the expiration of different periods. The following is a description of the sources of the samples of milk treated in this way : 
1. Milk from a mixed herd of cows, delivered December 7, 1896.

2. Morning's milk from Cheshire Dairy Institute, December 10, 1896, being the mixed milk of 28 shorthorn and 2 Jersey cows; 20 calved March and April, 1896, and the other 10 since the middle of October. Daily rations : $4 \mathrm{lb}$. decorticated cotton-cake, $2 \mathrm{lb}$. maize meal, $2 \mathrm{lb}$. bran, and hay ad lib.

3. Evening's milk from above herd, December 9, sampled in morning of December 10. The cream evidently had not been thoroughly mixed with the milk.

4. Milk from 4 Dutch cows on Lord Egerton's estate, December 18, 1896 ; calved respectively October 30, September 31, September 28, and August 20. Food : Indian meal, linseed cake, bran, meal, hay, and mangolds.

5. Milk from 4 dairy shorthorns on Lord Egerton's estate, December 18, 1896 ; calved respectively August 30, August 27, June 26, and June 15. Food as No. 4.

6. Milk from 4 Jersey cows on Lord Egerton's estate, December 18, 1896 ; calved respectively October 24, September 15, September -, and September -. Food as No. 4.

7. Milk from 4 Kerries on Lord Egerton's estate, December 18, 1896 ; calved respectively August 16, June 30, February 26, and February 20. Food as No. 4.

8. Mixed morning milk from farm of Cheshire Dairy Institute, January 25, 1897. Herd and feeding same as No. 2.

9. Mixed evening milk from farm of Cheshire Dairy Institute, January 24, 1897 ; taken same evening. Herd and feeding same as No. 2.

The table on next page gives the original composition of the samples, the percentage composition of the solids-not-fat, the contents of nitrogen-stated as casein and albumin-and the percentage loss of weight in each sample at the time the estimation was made.

From these results it is evident that, under the conditions obtaining in these experiments, the loss of nitrogen on keeping the milk for periods up to twenty-six weeks is nil, or, at all events, does not exceed what may reasonably be deemed errors of manipulation ; and it seems to us, therefore, that so long as a sample of milk has an acid reaction, an estimation of the nitrogen enables the analyst to infer with a probability amounting almost to certainty what was the original contents of casein and albumen in the sample, the only uncertainty being the loss of weight the sample has undergone on keeping.

On finding in the earlier stages of our investigation that our presumption that the nitrogen contents of a sample of milk remained constant on keeping, we obtained other samples from different sources, with a view of ascertaining to what extent the percentages of the albumen and casein varied in milk from different sources, and to what extent these enabled the analyst to infer adulteration or otherwise.

The samples examined were as follows :

10. Milk from a Liverpool dairy, stall fed, February 16, 1897. Feeding unknown. 


\begin{tabular}{|c|c|c|c|c|c|c|c|c|c|}
\hline & $\begin{array}{c}1 . \\
\text { Milk } \\
\text { from } \\
\text { a Dairy, } \\
\text { Rock } \\
\text { Ferry. } \\
\end{array}$ & \begin{tabular}{|}
2. \\
Morning's \\
Milk from \\
Dairy \\
Institute, \\
Worleston, \\
Cheshire, \\
28 Short- \\
horns, \\
2 Jerseys, \\
Dec. 10, 1896.
\end{tabular} & \begin{tabular}{|} 
3. \\
Evening's \\
Milk from \\
Dairy \\
Institute, \\
Worleston, \\
28 Short- \\
horns, \\
2 Jerseys, \\
Dee. 9, 1896. \\
\end{tabular} & $\begin{array}{c}4 . \\
\text { Milk } \\
\text { from } \\
\text { 4 Dutch } \\
\text { Cows. } \\
\end{array}$ & $\begin{array}{c}5 . \\
\text { Milk } \\
\text { from } \\
\text { 4 Dairy } \\
\text { Short- } \\
\text { horns. }\end{array}$ & $\mid \begin{array}{c}6 . \\
\text { Milk } \\
\text { from } \\
\text { 4 Jerseys. }\end{array}$ & $\underset{\substack{\text { Milk } \\
\text { from } \\
4 \text { Kerries. }}}{\substack{7 . \\
\text {. }}}$ & $\begin{array}{l}8 . \\
\text { Morning's } \\
\text { Milk from } \\
\text { Dairy } \\
\text { Institute, } \\
\text { Worleston, } \\
\text { 28 Short- } \\
\text { horns, } \\
\text { 2 Jerseys, } \\
\text { Jan. 25, } \\
\text { 1897. }\end{array}$ & $\begin{array}{l}9 . \\
\text { Evening's } \\
\text { Milk from } \\
\text { Dairy } \\
\text { Institute, } \\
\text { Worleston } \\
\text { 28 Short- } \\
\text { horns, } \\
\text { 2 Jerseys, } \\
\text { Jan. 24, } \\
1897 .\end{array}$ \\
\hline Water - - - & $87 \cdot 43$ & $87 \cdot 56$ & $89 \cdot 68$ & $88: 55$ & $87 \cdot 23$ & $84: 55$ & $85 \cdot 64$ & $87 \cdot 81$ & $87 \cdot 30$ \\
\hline $\begin{array}{l}\text { Fat } \\
{ }^{*} \text { Casein }{ }^{-} \text {and } \\
-\end{array}$ & $3 \cdot 35$ & $4 \cdot 05$ & $1 \cdot 80$ & $3 \cdot 25$ & $4 \cdot 07$ & $6 \cdot 21$ & $5 \cdot 05$ & $3 \cdot 77$ & $4 \cdot 41$ \\
\hline$(\mathbf{N} \times 6.33)$ & $3 \cdot 48$ & $3 \cdot 37$ & $3 \cdot 40$ & $2 \cdot 93$ & $3 \cdot 43$ & $3 \cdot 93$ & $4 \cdot 15$ & $3 \cdot 26$ & $3 \cdot 22$ \\
\hline Milk, sugar, etc. - & $4 \cdot 94$ & $4 \cdot 24$ & $4 \cdot 32$ & $4 \cdot 56$ & $4 \cdot 50$ & $4 \cdot 51$ & $4 \cdot 40$ & $4 \cdot 39$ & $4 \cdot 36$ \\
\hline Ash $-\quad-\quad-$ & $\cdot 80$ & $\cdot 78$ & $\cdot 80$ & $\cdot 71$ & $\cdot 77$ & $\cdot 80$ & $\cdot 76$ & $\cdot 77$ & $\cdot 71$ \\
\hline & $100 \cdot 00$ & $100 \cdot 00$ & $100 \cdot 00$ & $100 \cdot 00$ & $100 \cdot 00$ & $100 \cdot 00$ & $100 \cdot 00$ & $100 \cdot 00$ & $100 \cdot 00$ \\
\hline *Containing nitrogen & $\cdot 549$ & 532 & $\cdot 537$ & $\cdot 463$ & .542 & $\cdot 621$ & $\cdot 655$ & .515 & .509 \\
\hline $\begin{array}{l}\text { Solids-not-fat } \\
\text { Percentage composition } \\
\text { of solids-not-fat : }\end{array}$ & $9 \cdot 22$ & $8 \cdot 39$ & $8 \cdot 52$ & $8 \cdot 20$ & $8 \cdot 70$ & $9 \cdot 24$ & $9 \cdot 31$ & $8 \cdot 42$ & $8 \cdot 29$ \\
\hline Casein and albumin & $37 \cdot 42$ & $40 \cdot 17$ & $39 \cdot 91$ & $3 \bar{\varsigma} \cdot 73$ & $39 \cdot 43$ & $42 \cdot 53$ & $44: 58$ & $38 \cdot 72$ & $38 \cdot 84$ \\
\hline Milk-sugar, etc. & $53 \cdot 90$ & $50 \cdot 53$ & $50 \cdot 70$ & $55 \cdot 61$ & $51 \cdot 72$ & $48 \cdot 81$ & $47 \cdot 26$ & $52 \cdot 14$ & $52 \cdot 59$ \\
\hline Ash - & $8 \cdot 68$ & $9 \cdot 30$ & $9 \cdot 39$ & $8 \cdot 66$ & $8 \cdot 85$ & $8 \cdot 66$ & $8 \cdot 16$ & $9 \cdot 14$ & $8 \cdot 57$ \\
\hline After 1 epel. & $100 \cdot 00$ & $100 \cdot 00$ & $100 \cdot 00$ & $100 \cdot 00$ & $100 \cdot 00$ & $100 \cdot 00$ & $100 \cdot 00$ & $100 \cdot 00$ & $100 \cdot 00$ \\
\hline Loss per cent. - & $\cdot 10$ & $\cdot 12$ & - & $\cdot 12$ & $\cdot 14$ & $\cdot 20$ & $\cdot 06$ & - & _- \\
\hline Casein and albumin & $3 \cdot 46$ & $3 \cdot 31$ & - & $2 \cdot 88$ & $3 \cdot 42$ & $3 \cdot 93$ & $4 \cdot 18$ & - & - \\
\hline After 2 weeks : & & & & & & & & & \\
\hline $\begin{array}{l}\text { Loss per cent. - } \\
\text { Casein and albumin }\end{array}$ & $\cdot 40$ & $\cdot 12$ & - & $\cdot 40$ & 23 & $\cdot 21$ & $\cdot 18$ & -10 & .06 \\
\hline $\begin{array}{l}\text { Casein and albumin } \\
\text { After } 3 \text { weeks: }\end{array}$ & $3 \cdot 46$ & $3 \cdot 42$ & - & $3 \cdot 02$ & $3 \cdot 52$ & $3 \cdot 89$ & $4 \cdot 20$ & $3 \cdot 22$ & $3 \cdot 22$ \\
\hline Loss per cent. - & $\cdot 39$ & $1 \cdot 00$ & - & - & - & - & - & 一 & - \\
\hline $\begin{array}{l}\text { Casein and albumin } \\
\text { After } 4 \text { weeks : }\end{array}$ & $3 \cdot 52$ & $3 \cdot 46$ & - & - & - & - & 一 & - & - \\
\hline Loss per cent. - & $\cdot 36$ & $2 \cdot 57$ & .33 & $\cdot 33$ & $\cdot 44$ & 36 & $\cdot 33$ & - & - \\
\hline $\begin{array}{l}\text { Casein and albumin } \\
\text { After } 5 \text { weeks: }\end{array}$ & $3 \cdot 55$ & $3 \div 29$ & $3 \cdot 44$ & $2 \cdot 89$ & $3 \cdot 51$ & $4 \cdot 01$ & $4 \cdot 21$ & - & 一 \\
\hline Loss per cent. - & - & - & - & - & - & - & - & $\cdot 24$ & $1 \cdot 21$ \\
\hline $\begin{array}{l}\text { Casein and albumin } \\
\text { After } 7 \text { reeks: }\end{array}$ & -- & - & 一 & - & - & - & - & $3 \cdot 15$ & $3 \cdot 19$ \\
\hline Loss per cent. - & - & - & - & 37 & $: 22$ & 75 & $\cdot 42$ & - & - \\
\hline $\begin{array}{l}\text { Casein and albumin } \\
\text { After } 8 \text { weeks : }\end{array}$ & 一 & - & - & $2 \cdot 88$ & $3: 39$ & $3 \cdot 86$ & $4 \cdot 05$ & - & - \\
\hline Loss per cent. - & - & - & - & $\ldots$ & - & - & - & $\cdot 17$ & $\cdot 82$ \\
\hline $\begin{array}{l}\text { Casein and albumin } \\
\text { After } 9 \text { weeks: }\end{array}$ & - & - & - & - & - & - & - & $3 \cdot 11$ & $3 \cdot 15$ \\
\hline Loss per cent. - & 87 & 41 & $\cdot 81$ & - & - & - & - & - & - \\
\hline Casein and albumin & $3 \cdot 46$ & $3 \cdot 30$ & $3 \cdot 36$ & - & - & - & - & - & - \\
\hline After 12 veeks: & & & & & & & & & \\
\hline Loss per cent. - & 1.57 & - & - & - & 一 & - & - & - & - \\
\hline $\begin{array}{l}\text { Casein and albumin } \\
\text { After } 13 \text { weelks: }\end{array}$ & $3 \bullet 53$ & - & & - & - & - & - & - & - \\
\hline Joss per cent. - & - & 62 & $\cdot 50$ & - & - & - & - & $1 \cdot 01$ & - \\
\hline Casein and albumin & - & $3 \cdot 48$ & $3 \cdot 45$ & - & - & - & - & $3 \cdot 11$ & - \\
\hline After 14 weeks: & & & & & & & & & \\
\hline Loss per cent. - & - & - & - & - & - & - & - & - & .01 \\
\hline $\begin{array}{l}\text { Casein and albumin } \\
\text { After } 19 \text { weeks. }\end{array}$ & - & & & - & - & - & - & - & $3 \cdot 15$ \\
\hline Loss per cent. - & - & - & - & $\cdot 49$ & $\cdot 44$ & $1 \cdot 13$ & $\cdot 70$ & - & - \\
\hline Casein and albumin & - & - & - & $2 \cdot 84$ & $3 \cdot 53$ & $4: 00$ & $4 \cdot 15$ & - & - \\
\hline $\begin{array}{l}\text { After } 21 \text { veeels: } \\
\text { Loss per cent. }\end{array}$ & - & - & $\ldots$ & - & - & - & - & $\cdot 61$ & .62 \\
\hline Casein and albumin & - & - & - & - & - & - & - & $3 \cdot 16$ & $3 \cdot 28$ \\
\hline $\begin{array}{l}\text { After } 26 \text { weels : } \\
\text { Loss per cent. }\end{array}$ & $\ldots$ & - & - & $1 \cdot 40$ & $\cdot 50$ & 1.42 & $1 \cdot 33$ & & \\
\hline $\begin{array}{l}\text { Loss per cent. - } \\
\text { Casein and albumin }\end{array}$ & - & - & - & $2 \cdot 81$ & $3 \cdot 39$ & $3 \cdot 86$ & $4 \cdot 15$ & - & - \\
\hline
\end{tabular}


11. Milk from another town dairy, February 23, 1897.

12. Milk delivered to a house at Crosby, March 9, 1897. Origin unknown.

13. Milk from a Cheshire farm near Warrington, March 10, 1897. Cows fed with clover hay, Indian corn, oats, swedes, and mangolds.

14. Mixed milk from 4 dairy shorthorns, April 1, from Lord Egerton's home farm, Tatton Park :

\begin{tabular}{|c|c|c|c|c|c|}
\hline \multirow{6}{*}{$\begin{array}{l}\text { "Trinket" } \\
\text { " Kirby Belle" } \\
\text { " Cuckoo" } \\
\text { "Chaffinch" }\end{array}$} & \multicolumn{3}{|c|}{ Yield of Milk. } & \multirow{2}{*}{\multicolumn{2}{|c|}{ Calved. }} \\
\hline & $\begin{array}{c}\text { Morning. } \\
\text { qts. }\end{array}$ & & $\begin{array}{c}\text { Evening. } \\
\text { qts. }\end{array}$ & & \\
\hline & .. 7 & $\ldots$ & 6 & $\cdots$ & August 30 \\
\hline & $4 \frac{1}{2}$ & $\ldots$ & 4 & $\ldots$ & August 27 \\
\hline & $7^{2}$ & $\ldots$ & 5 & $\ldots$ & February 19 \\
\hline & $\ldots$ & $\ldots$ & $4 \frac{1}{2}$ & $\ldots$ & February 20 \\
\hline Daily ratio & 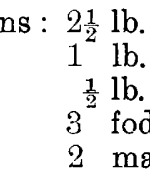 & $\begin{array}{l}\text { ndic } \\
\text { ake } \\
\text { ran } \\
\text { erin }\end{array}$ & $\begin{array}{l}\text { meal } \\
\text { ach ad } \\
\text { ach a d } \\
\text { s (with }\end{array}$ & $\begin{array}{l}\text { y. } \\
\text { y. } \\
\text { nead }\end{array}$ & a meal. \\
\hline
\end{tabular}

15. Mixed milk from 4 Dutch cows, April 1, 1897 :

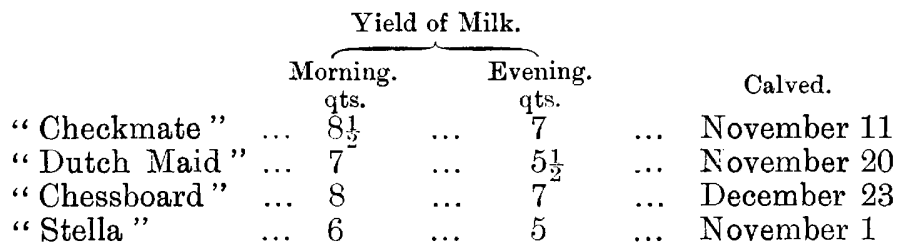

Daily rations same as No. 14.

16. Mixed milk from 4 Kerries, April 1, 1897 :

$$
\begin{aligned}
& \text { Yield of Milk. }
\end{aligned}
$$

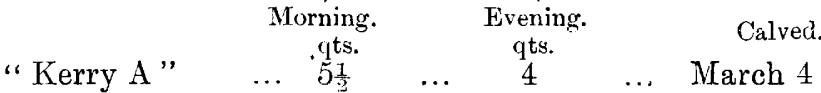

$$
\begin{aligned}
& \begin{array}{lllllll}
\text { "Kerry K" } & \ldots & 4 \frac{1}{2} & \ldots & 3 & \ldots & \text { February } 14
\end{array}
\end{aligned}
$$

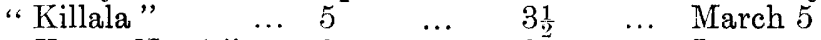

$$
\begin{aligned}
& \text { “ Kerry No. } 1 \text { ” .. } 3 \frac{1}{2} \quad \ldots \quad 2 \quad 2 \frac{1}{2} \quad \ldots \quad \text { January } 29
\end{aligned}
$$

Daily rations : $1 \frac{3}{4} \mathrm{lb}$. Indian meal each a meal.

$\frac{1}{3}$ lb. cake each per day.

lb. bran each per day.

2 mangolds each per day.

3 fodderings (of meadow hay).

17. Mixed milk from 4 Jersey cows, April 1, 1897 :

$$
\begin{aligned}
& \text { Yield of Milk. } \\
& \text { "Phyllis" }
\end{aligned}
$$

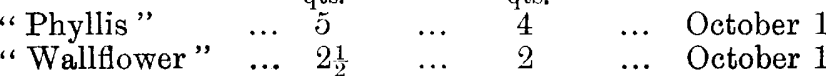

$$
\begin{aligned}
& \text { " "Buttercup" } \\
& \begin{array}{lllllll}
\text { "Tulip" } & \ldots & 4 \frac{1}{2} & \ldots & 4 & \ldots & \text { October } 24 \\
& \ldots & 3 \frac{1}{2} & \ldots & 3 & \ldots & \text { October } 1
\end{array}
\end{aligned}
$$

Daily rations same as No. 14 . 
18. Milk taken at Stockport by inspector under Sale of Food and Drugs Act, April 13, 1897.

19. Ditto, ditto (another sample), April 13, 1897.

On analysing in the same manner as before the accompanying results were obtained :

\begin{tabular}{|c|c|c|c|c|c|c|c|c|c|c|}
\hline \multirow{5}{*}{$\begin{array}{l}\text { Water - } \\
\text { Fat } \\
{ }^{*} \text { Casein and albu- } \\
\quad \min (\mathrm{N} \times 6 \cdot 33)\end{array}$} & $\begin{array}{l}10 . \\
\text { Liver- } \\
\text { pool } \\
\text { Dairy. } \\
\text { Town } \\
\text { fed. }\end{array}$ & $\begin{array}{l}11 . \\
\text { Liver- } \\
\text { pool } \\
\text { Dairy. } \\
\text { Town } \\
\text { fed. }\end{array}$ & $\mid \begin{array}{c}12 . \\
\text { De- } \\
\text { livered at } \\
\text { Crosby. }\end{array}$ & $\begin{array}{c}13 . \\
\text { Cheshire } \\
\text { Farm, } \\
\text { near } \\
\text { Warring- } \\
\text { ton. }\end{array}$ & $\begin{array}{l}14 . \\
\text { From } \\
\text { Dairy } \\
\text { Short- } \\
\text { horns. }\end{array}$ & $\begin{array}{l}15 . \\
\text { From } 4 \\
\text { Dutch } \\
\text { Cows. }\end{array}$ & $\begin{array}{l}16 . \\
\text { From } 4 \\
\text { Kerry } \\
\text { Cows. }\end{array}$ & $\begin{array}{l}17 . \\
\text { From } 4 \\
\text { Jersey } \\
\text { Cows. }\end{array}$ & $\begin{array}{l}18 . \\
\text { From } \\
\text { Stock- } \\
\text { port. }\end{array}$ & $\begin{array}{l}19 . \\
\text { From } \\
\text { Stock. } \\
\text { port. }\end{array}$ \\
\hline & $86 \cdot 62$ & $88 \cdot 11$ & $87 \cdot 21$ & $87 \cdot 41$ & $87 \cdot 81$ & $88 \cdot 76$ & $86 \cdot 29$ & $84 \cdot 15$ & $86 \cdot 86$ & $87 \cdot 19$ \\
\hline & $4 \cdot 92$ & $3 \cdot 10$ & $4 \cdot 03$ & $3 \cdot 72$ & $3 \cdot 69$ & $3 \cdot 21$ & $5 \cdot 02$ & $6 \cdot 35$ & $4 \cdot 39$ & $4 \cdot 30$ \\
\hline & $3 \cdot 68$ & $3 \cdot 46$ & $3 \cdot 78$ & $3 \cdot 65$ & $3 \cdot 33$ & $2 \cdot 74$ & $3 \cdot 33$ & 4.04 & 3.51 & $3 \cdot 28$ \\
\hline & $4 \cdot 01$ & 4.56 & $4 \cdot 20$ & $4 \cdot 4 \cdot 0$ & $4 \cdot 44$ & 4.57 & $4 \cdot 65$ & $4 \cdot 72$ & $4 \cdot 47$ & $4 \cdot 36$ \\
\hline \multirow[t]{2}{*}{ Ash - } & $\cdot 77$ & $\cdot 77$ & .78 & .82 & .73 & $\cdot 72$ & 71 & $\cdot 74$ & $\cdot 77$ & $\cdot 87$ \\
\hline & $100 \cdot 00$ & $100 \cdot 00$ & $100 \cdot 00$ & $100 \cdot 00$ & $100 \cdot 00$ & $100 \cdot 00$ & $100 \cdot 00$ & $100 \cdot 00$ & $100 \cdot 00$ & $100 \cdot 00$ \\
\hline \multirow{5}{*}{$\begin{array}{l}{ }^{*} \text { Containing nitro- } \\
\text { gen - } \\
\text { Solids-not-fat } \\
\text { Percentage compo- } \\
\text { sition of solids- } \\
\text { not-fat : } \\
\text { Casein and albu- } \\
\text { min - } \\
\text { Milk-sugar, etc. } \\
\text { Ash - - }\end{array}$} & $\begin{array}{c}\cdot 581 \\
8 \cdot 46\end{array}$ & $\begin{array}{c}\cdot 546 \\
8 \cdot 79\end{array}$ & $\begin{array}{c}597 \\
8 \cdot 76\end{array}$ & $\begin{array}{c}\cdot 576 \\
8 \cdot 87\end{array}$ & $\begin{array}{c}\cdot 526 \\
8 \cdot 50\end{array}$ & $\begin{array}{c}\cdot 434 \\
8 \cdot 03\end{array}$ & $\begin{array}{c}\cdot 525 \\
8.69\end{array}$ & $\begin{array}{c}\cdot 639 \\
9 \cdot 50\end{array}$ & $\begin{array}{c}\cdot 554 \\
8 \cdot 75\end{array}$ & $\begin{array}{c}\cdot 518 \\
8.51\end{array}$ \\
\hline & & & & & & & & & & \\
\hline & $47 \cdot 40$ & 51.87 & $47 \cdot 95$ & $49 \cdot 60$ & $52 \cdot 23$ & $56 \cdot 91$ & $53 \cdot 51$ & $49 \cdot 69$ & $51 \cdot 09$ & $51 \cdot 24$ \\
\hline & $9 \cdot 10$ & $8 \cdot 77$ & $8 \cdot 90$ & $9 \cdot 25$ & $8 \cdot 59$ & $8 \cdot 97$ & $8 \cdot 17$ & $7 \cdot 79$ & $8 \cdot 80$ & $10 \cdot 22$ \\
\hline & $100 \cdot 00$ & $100 \cdot 00$ & $100 \cdot 00$ & $100 \cdot 00$ & $100 \cdot 00$ & $100 \cdot 00$ & $100 \cdot 00$ & $100 \cdot 00$ & $100 \cdot 00$ & $100 \cdot 00$ \\
\hline
\end{tabular}

From the whole of the analyses it will be noticed that, with the exception of the milk from the Dutch cows, the lowest percentage $(3 \cdot 22)$ of albuminoids is in No. 9 a result slightly above that suggested by Mr. Richmond as a limit (ANaLyst, xxii. 94). The average percentage of albuminoids is $3 \cdot 466$. If the milk from the Dutch (which gives in both cases milk of a very poor character), the Kerry, and Jersey cows, which do not as a rule form any appreciable proportion of the herads kept for the production of milk for towns' supplies, be omitted, the average percentage is $3 \cdot 448$.

The average percentage of milk-sugar obtained by difference is 4.45 , with 4.01 as a minimum, and 4.97 per cent. as a maximum.

From the results of the analyses it will be observed that the variations in the percentages of casein and albumin are greater than those of the solids-not-fat, and consequently the nitrogen is a less satisfactory factor in determining adulteration than the sum of the total solids-not-fat. Nevertheless, as it enables the analyst to calculate with a great degree of accuracy the original contents of the casein and albumin, it offers, in conjunction with the ash, a means of control in the analysis of decomposed milks probably more accurate than any system depending upon the estimation of the total solids and a correction for decomposition, when the nature of the decomposition is unknown. 


\section{Discussion.}

The President said that this contribution from Mr. Smetham and Mr. Ashworth came as a matter of considerable interest just after the suggestion lately made by Mr. Richmond, who did not know at the time that this work was in progress. One point that was brought out in these analyses was a point which Mr. Richmond had emphasized before, viz., that the most constant figure in a milk analysis was the milk-sugar. Unfortunately, however, it was the item which underwent most change on keeping. Working out the ratio of nitrogen to non-fatty solids in these analyses, he noticed that the variation was considerable, being from $1: 14$ in the case of the Kerry cows to $1: 18$ in the Dutch cows, the lowness of the non-fatty solids in the latter case probably being partly due to a deficiency of nitrogenous constituents. These Dutch cows occasionally caused trouble. He had met with cases himself in which farmers had got into trouble by relying upon Dutch cows, or by selling the milk of Dutch cows which they happened to possess, without mixing it in with the rest of the milk from a miscellaneous herd. Mr. Allen had written to him expressing regret at being unable to attend the meeting, and mentioning that he had a high opinion of the value of the nitrogen factor in the analysis of decomposed milks, and saying that in the forthcoming volume of his work on "Commercial Organic Analysis" he was suggesting a limit of 0.5 per cent. of nitrogen, which was also the figure proposed by Mr. Richmond.

Mr. RIchmond said he considered the paper a very valuable one. He believed that this was the first series of systematic nitrogen determinations in milk after keeping that had yet been published, and he might say that the results agreed entirely with his own experience, although he could not claim to have made a systematic series of determinations. The most important point in the paper seemed to him to be the low proportion, both of solids-not-fat and of casein and albumin, yielded by the Dutch cows. He had had no opportunity for noticing this in his own experience, for he had not analysed any samples taken from those cows alone, which formed an infinitesimal minority among the herds from which the milk that he examined was drawn. It seemed to him, however, that the milk of Dutch cows was more or less abnormal. Similar results to those recorded by the authors had been observed in the United States at the New Jersey Experiment Station in the case of cows of a practically identical breed. The nitrogen in many cases fell distinctly below 0.5 per cent., the ash below 0.7 , and the solids-not-fat frequently as low as 8 per cent. He thought that, in considering any limits that might be fixed for milk, these cows must be taken into account. It would hardly do to declare that the product of Dutch cows was not milk. The farming interest of the country would claim to be allowed to keep any particular breed of cows that they chose, and also that the normal product of these animals, whatever their breed might be, was entitled to be considered as milk. It would be for the Society of Public Analysts, or any other body that might have to fix limits for milk, to consider how far the Dutch cows would affect the figures that were chosen. In the first portion of the paper some figures were given as to the acidity of milk, estimated as lactic acid, and it was stated that milk containing 0.22 per cent. of acidity as lactic acid showed, after heating to $100^{\circ} \mathrm{C}$, a 
diminution of the lactic acid to $0 \cdot 11$ per cent. He would like to ask the authors how they accounted for this. He had himself found practically the same thing, and his own idea was that the phenomenon was to be largely accounted for by the deposition of acid calcium salts, to which a large proportion of the acidity of milk was due. $\mathrm{He}$ would like to know whether the authors agreed with him in this, or whether they had any other explanation to suggest. He would also like to draw attention to the fact that, in estimating the acidity of sour milk, when phenol-phthalein was used, the dissolved carbon dioxide was estimated, and the acidity, if calculated to lactic acid, would be largely in excess of the true lactic acid present. It was by no means uncommon for a milk which had been kept some time and which was distinctly sour, to show as much as 2 per cent. of lactic acid, which he believed was a quantity that was not formed by the lactic ferment; the real lactic acid would in such a case be perhaps about half this amount.

Mr. R. W. Woosnam remarked that the nitrogen determinations mentioned in the paper had all been made on samples carefully weighed out while still fresh. He did not know how the authors would deal with a sample that had been bottled up for about six weeks, the condition of which would probably be very bad indeed. He supposed they would follow the usual plan of neutralizing with caustic soda and shaking vigorously, but it would be very difficult to get a fair sample at all in such a case.

Mr. Richmond observed that an excellent method for mixing up decomposed milks was described in Dr. James Bell's work on foods. It consisted in whisking the milk with a small brush made of fine brass wire. In his own hands it had worked extremely well, determinations of fat made in sour milks agreeing very well with those made on the same milks when fresh, even when the milk was badly curdled and the cream all separated out on the top.

Mr. Cassal said he could confirm what Mr. Richmond had just said as to the possibility of mixing decomposed milks and getting fairly accurate determinations of fat in them. He thought, however, that while this could undoubtedly be done satisfactorily when the weather had not been abnormally hot, yet in very hot summers, such as had been experienced within recent years, forms of decomposition would set in which practically broke up the milk altogether, and there was no longer any possibility of getting even an accurate determination of the fat under such circumstances. He did not know whether the authors had carried out any experiments upon samples of milk which had been kept at abnormally high temperatures, but from his own experience he might mention that it was a matter well worthy of their attention. A point of interest in connection with this method, in view of the existing necessity for stating analytical details in certificates given under the Sale of Food and Drugs Act, upon samples of watered milk, was that there was nothing to prevent an analyst from forming his opinion as to the purity of a sample of milk from such a factor as the nitrogen. It was a matter of considerable interest to him to find that Mr. Richmond, Mr. Smetham, and Mr. Allen were now suggesting a limit of 0.5 per cent. of nitrogen, as he (Mr. Cassal) had had occasion to state in court that a public analyst was not bound to found his opinion upon the solids-not-fat figure, and that he might, for instance, base his opinion on the amount of nitrogen. He presumed that they would consider anything very much below 0.5 to be indicative of adultera- 
tion. If satisfactory results could be obtained by using this figure, instead of making out his certificate in the form recommended by the Society of Public Analysts, a public analyst could state that the percentage of nitrogen was the basis on which he had formed his opinion. It would be interesting if the authors could give some further information with regard to the "Dutch cows" referred to in the paper. It was quite plain that a liquid drawn from a cow's udder was not necessarily milk, and he suggested that the "Dutch cow" was no better than the remarkable " single cow" whose curious products had been so often called attention to. Far more information, of a trustworthy kind, would have to be obtained before any importance could be attached to the "Dutch" and " single cow" results.

Mr. R. A. CRIPPs remarked that whenever the percentage of non-fatty solids was considered to be unduly low, it would appear desirable that the inferences drawn from this should be confirmed by a determination of the nitrogen.

Dr. RIDEAL remarked that, although the figures were conclusive as to the absence of any evolution of nitrogen under the conditions of these experiments, it was by no means certain that, under ordinary practical conditions, changes might not take place after some time, resulting in an appreciable loss of nitrogen.

The President said that before asking Mr. Smetham to reply he would like to mention the fact that many Dutch cows did contribute to the milk-supply of London. Dutch cow's were sometimes kept by dairy farmers on account of their very copious yield of milk. They yielded poor milk, but a large quantity of it. Thanks, however, to the activity and watchfulness of companies and wholesale frms such as those for whom Mr. Richmond and Mr. Woosnam acted, a pretty sharp watch was kept upon these large milk producers, and if they kept a fair number of Dutch cows they had to keep a large number of shorthorns as well, in order to swamp the poor quality of the Dutch milk. During the two previous years of drought a good many samples of milk had been sent to him by indignant vendors, who had received unpleasant letters from the wholesale dealers whom they supplied, on account of their milk coming dangerously near to or just passing the limits prescribed by the Society of Public Analysts. But in years of drought there was no doubt a tendency for all milk to be rather poor, and then the poverty of the Dutch cows very often made its effect felt, despite the mixture of the milk with that of shorthorns. He did not think many people would keep Dutch cows only, or that, if a man kept only a few cows, he would choose Dutch ones, as it would be too risky. What the Society of Public Analysts was hoping for was to obtain a legal definition of milk, or, rather, to get powers given to that Reference Committee which it was hoped would be legally constituted, to declare from time to time a definition of milk which would have the force of law. Then, no doubt, if it were decided that when a purchaser asked for " milk" he was entitled to get something containing 8.5 per cent. of non-fatty solids and so much fat, the vendor would use Dutch cows at his own risk and peril. A magistrate would probably take a lenient view in such a case if the man could prove the genuineness' of his milk; but what they hoped was that they would get, through legal machinery, some such definition as would at any rate leave the onus probandi on the vendor in the case of anything falling below the limit fixed. Phenolphthalein always seemed to him to be a misleading indicator to use for determining acidity in a fluid 
like milk, determining, as it did, the carbonic acid, which did not represent acidity in the sense of the term as used in reference to milk.

Mr. Smetham said that, although Dutch cows appeared to be used to some extent in the South, they had not, except in a few instances, penetrated to any large extent into the North. Lord Egerton, however, had on his estate a considerable herd, and it was from this herd that he (Mr. Smetham) had obtained all the samples of milk from Dutch cows which they had examined. It was, perhaps, unfortunate, but he figured out from the cost of feeding, the production of milk, etc., in the case of the last four Dutch cows, as compared with shorthorns and Jerseys fed at the same time, that the Dutch cows were the most profitable. The quantity of butter yielded per day by the shorthorns was $4.05 \mathrm{lb}$.; the Dutch cows gave $4.33 \mathrm{lb}$, the Kerrys $3.96 \mathrm{lb}$, and the Jerseys $4.50 \mathrm{lb}$. Of casein and albumin together the shorthorns gave $3.66 \mathrm{lb}$. per day, the Dutch $3.80 \mathrm{lb}$, the Kerrys $2.63 \mathrm{lb}$., and the Jerseys $2.87 \mathrm{lb}$. The Jerseys were, therefore, the most profitable from a butter-making point of view, but for cheese-making the Dutch were undoubtedly the most valuable, giving much more casein than any of the others. From the point of view of the farmer, whatever they might be from the consumer's point of view, the Dutch were undoubtedly the most economical cows to keep. With regard to the variations that had been alluded to, it had been pointed out in the paper that any calculations based upon the nitrogen factor were not as accurate throughout the whole of these tests as those based on the total solids-not-fat. Of course, the percentage of solids-not-fat recorded in the case of the Dutch cows would in itself represent about 7 per cent. of adulteration; if the percentage of solids-not-fat had been normal, no doubt the nitrogen would have been higher. He might mention that on several previous occasions he had examined milk from Dutch cows, and had always found it exceedingly poor, generally containing less than 8.5 per cent. of non-fatty solids. His experience, however, had been limited entirely to Lord Egerton's estate, and possibly there might be something in the climate or soil of that part of the country which gave rise to these abnormal results. So far as feeding was concerned, these cows were treated in exactly the same way as the Jerseys, which gave $9 \frac{1}{2}$ per cent. of solidsnot-fat. They had used phenolphthalein as an indicator because of its very easy working and the very accurate results that it gave, but the figures for acidity stated in the paper represented the total acidity, from whatever source, and he did not for a moment wish to assume that it was all due to lactic acid. It was very possible, though he was not prepared to say that it was so, that the explanation suggested by Mr. Richmond for the loss of acidity in the milk after boiling was the correct one. He himself, however, rather preferred to look upon it as due to the presence of carbonic acid; but he had made no experiments to prove this, and only knew that they obtained in the milk as it came from the cow a result higher than that given by the same milk after it had been carried from the cow and mixed in a vat. The next day they took some milk direct from the cow and boiled it, and found that there was the dimunition in acidity which they had referred to, and which he attributed, rightly or wrongly, to loss of carbonic acid. With regard to Mr. Woosnam's remarks, he desired to point out that, although these samples were carefully weighed out while the milk was fresh, any difficulties 
caused by bad condition of samples would have to be dealt with, whatever might be the mode of analysis. Difficulties from this cause were inherent to the analysis of a decomposed milk, but he thought the nitrogen determination would probably be affected in a less degree than any other. It would scarcely be possible to take 20 grammes for the determination of the total solids or the ash, but this quantity could be taken for the nitrogen determination, and was, in fact, about the best quantity to work on. This was a great advantage in favour of the Kjeldahl process. With regard to the temperature at which the experimental samples had been kept, there had been no attempt made to regulate it. The samples were in small bottles closed by corks, the bottles having been first sterilized. They were kept for a period extending from December, 1896, until the end of April, 1897, when some of these determinations were made, and although there had been no hot weather, some of them had occasionally been subjected to a rather high temperature, for at times the laboratory temperature rose as high as $70^{\circ} \mathrm{F}$. So far as the experiments had gone, there was no appreciable loss of nitrogen, but they had been careful not to say that there could not be loss of nitrogen under conditions other than those under which the experiments were carried out. The Worleston milk was from an experimental farm belonging to the Cheshire County Council, and the feeding of the cows was as stated in the paper. He had for two years carried on experiments on this farm, and there was no doubt that very often, from one cause or another, the total solids of this milk fell to 8.5 and even lower. No doubt, as Mr. Bevan had said, the ash was a very constant constituent of milk, and a very good indication of its purity or otherwise, but it needed to be determined with considerable care. It was not an uncommon thing for inexperienced operators to get results that were too low, owing to volatilization of alkaline salts resulting from the use of too intense a flame. There was also the objection that if boric acid or a borate were present, the calculation was upset. He had made some experiments with regard to the percentage of phosphates in the ash of milk, and had found that phosplates formed a very constant constituent. The advantage, however, which the nitrogen had over the ash was that, except in the shape of ammonia salts, there was no very easy way in which a milkman could add any nitrogenous compound to the milk, and few would be likely to know how to add ammonia salts, or where to buy them. 